\title{
Changes in smoking habit among patients with a history of oral squamous cell carcinoma (OSCC)
}

\author{
Rafael Poveda-Roda ${ }^{1}$, José V. Bagán ${ }^{2}$, Yolanda Jiménez-Soriano ${ }^{3}$, Maria Margaix-Muñoz ${ }^{4}$, Gracia Sarrión- \\ Pérez $^{4}$ \\ ${ }^{1}$ Staff physician. Service of Stomatology. Valencia University General Hospital \\ ${ }^{2}$ Chairman of Oral Medicine. Department of Stomatology. University of Valencia. Head of the Service of Stomatology. Valencia \\ University General Hospital \\ ${ }^{3}$ Contracted physician and lecturer. Department of Stomatology. University of Valencia \\ ${ }^{4}$ Collaborating dental surgeon. Service of Stomatology. Valencia University General Hospital
}

Correspondence:

Av./Tres Cruces $n^{\circ} 2$

46014 Valencia, Spain

poveda@uv.es

\begin{abstract}
Poveda-Roda R, Bagán JV, Jiménez-Soriano Y, Margaix-Muñoz M, Sarrión-Pérez MG. Changes in smoking habit among patients with a history of oral squamous cell carcinoma (OSCC). Med Oral Patol Oral Cir Bucal. 2010 Sep 1;15 (5):e721-6.
\end{abstract}

Received: 10/10/2009 Accepted: 24/12/2009

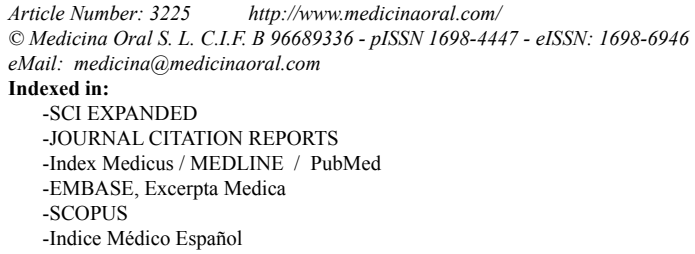

\begin{abstract}
Objective: To determine the changes in smoking habit among patients with oral squamous cell carcinoma (OSCC) diagnosed and treated in the Service of Stomatology (Valencia University General Hospital. Valencia, Spain).

Material and methods: The study involved 123 patients with a history of OSCC interviewed by telephone on their smoking habits at the time of the diagnosis and modifications in habits subsequently. The mean age at diagnosis was 60 years and 9 months (standard deviation, $\mathrm{SD} \pm 12$ years and 2 months). Males predominated (61.8\%) over females $(38.2 \%)$. The mean time from the diagnosis of OSCC to the survey was 4 years and 6 months (SD \pm 3 years and 6 months).

Results: Almost one-half of the patients (45.5\%) were active smokers at the time of the diagnosis, with a mean duration of the habit of 34.9 years ( $\mathrm{SD} \pm 12$ years and 7 months). In turn, $19.5 \%$ of the patients were ex-smokers at diagnosis, with an average of 13 years and 9 months ( $\mathrm{SD} \pm 9$ years and 4 months) from smoking cessation to the development of cancer. A total of $57.1 \%$ of the smokers abandoned the habit at diagnosis, $8.9 \%$ continued to smoke to the same extent as before, and $33.9 \%$ reduced smoking.

Conclusion: A full $44.4 \%$ of our patients diagnosed with OSCC continued to smoke despite warnings of the risks, and although the majority claimed to have reduced their smoking habit, interventional strategies would be indicated to help ensure complete smoking cessation.
\end{abstract}

Key words: Smoking, oral cancer, oral squamous cell carcinoma, modification of smoking habit. 


\section{Introduction}

The association between tobacco smoking and cancer is one of the most important paradigms in modern epidemiology (Fig. 1). Malignant tumors of the oral cavity represent about $3 \%$ of all malignancies, and of these, $90 \%$ correspond to oral squamous cell carcinoma (OSCC). The estimated incidence is 5.1 cases / 100,000 inhabitants/year (1). Although a number of factors have been related to the etiopathogenesis of oral malignancies (alcohol, human papilloma virus, Epstein-Barr virus, a lack of fruit and vegetables in the diet, periodontal disease, genetic factors) (2), smoking is the main risk factor associated with oral cancer, and particularly with OSCC (3). The prevalence of OSCC in cigarette smokers is estimated to be 4-7 times greater than in non-smokers (4). This circumstance represents the third most significant association between smoking and cancer, following lung cancer (hazard ratio: 15.0-30.0) and laryngeal cancer (hazard ratio: 10.0) (5). According to Petti, 25\% of all oral malignancies are attributable to both smoked and chewed tobacco (6), and the risk of oral, pharyngeal and esophageal cancer begins to be significantly higher in smokers starting from levels as low as two cigarettes a day. This indicates that there is no harmless level of smoking (7).

The existence of an undeniable link between smoking and OSCC reasonably should lead to total smoking cessation among patients who have been diagnosed with the disease and who have been duly informed of its seriousness, of the role played by tobacco, and of the important risk of tumor relapse if smoking continues. Unfortunately, this is not the case, and many patients continue to smoke despite such considerations.

The main objective of the present study was to determine the changes in smoking habit in a group of 123 pa-

\begin{tabular}{|l|l|}
\hline $\begin{array}{l}\text { Evidence of a relationship between } \\
\text { smoking and cancer }\end{array}$ & $\begin{array}{l}\text { Suspected relationship between } \\
\text { smoking and cancer }\end{array}$ \\
\hline Oral cavity and pharynx & Adenomatous colorectal polyps \\
Larynx & Colon \\
Lungs and bronchi & Rectum \\
Esophagus & Liver* \\
Stomach & Breast \\
Pancreas & \\
Bladder & \\
Cervix & \\
Kidneys and renal pelvis & \\
Acute myeloid leukemia & \\
\hline
\end{tabular}

Fig. 1. Association between smoking and cancer in different organs.

* The IARC (International Agency for Research on Cancer) considers that there is sufficient evidence of a causal relationship between smoking and liver cancer. tients diagnosed with OSCC and treated in the Service of Stomatology (Valencia University General Hospital. Valencia, Spain).

\section{Material and Methods}

The study was carried out in the Service of Stomatology (Valencia University General Hospital. Valencia, Spain) between February and May 2009, following approval by the Clinical Research Ethics Committee of the hospital. The study included a total of 123 patients with a histologically confirmed diagnosis of OSCC, and with a mean time from diagnosis to the study interview of 4 years and 6 months $(\mathrm{SD} \pm 3$ years and 6 months; range 3-166 months). The mean patient age at the time of the diagnosis was 60 years and 9 months $(\mathrm{SD} \pm 12$ years and 2 months; range 25-92 years). There were 76 males (61.8\%) and 47 females (38.2\%).

A telephone interview was made to document information on the smoking habit at the time of the diagnosis, the duration of the habit, and the daily consumption rate. The patients were also asked about their smoking habit at the time of the interview, and whether they had stopped smoking at some point. In the case of patients that did not smoke at the time of the diagnosis, the interview was completed by asking them whether they had ever smoked in the past. All the patients initially agreed to participate in the study $(\mathrm{n}=130)$. However, 7 of them could not be contacted by telephone. As a result, the final sample consisted of 123 patients (loss rate 5.4\%). Only patient reported smoking habit was considered, without biochemical validation in the form of cotinine determination in saliva, urine or blood.

The data were coded, tabulated and analyzed using the SPSS version 15.0 statistical package (SPSS ${ }^{\circledR}$, Chicago, IL, USA). For data analysis, use was made of the binomial test for differences of absolute values, the Pearson chi-squared test for the comparison of proportions, and the Student t-test for the comparison of means.

\section{Results}

(Table 1) shows the most relevant epidemiological and clinical characteristics of the study sample. At the time of diagnosis, $45.5 \%$ of the patients $(\mathrm{n}=56)$ were active smokers. Of these, $67.9 \%$ consumed more than one packet of cigarettes a day (20 cigarettes per packet). The mean duration of the smoking habit up until the development of OSCC was 34 years and 9 months (SD \pm 12 years and 7 months), with a range of 6-59 years. This duration was significantly shorter in females (25 years and 8 months ( $\mathrm{SD} \pm 9$ years and 3 months) than in males (36 years and 8 months ( $\mathrm{SD} \pm 12$ years and 5 months) (ts $=2.61 ; \mathrm{p}<0.05)$, despite the absence of gender differences in the number of cigarettes smoked daily. In addition, 24 patients (19.5\%) were ex-smokers at the time of the diagnosis. The mean duration of the habit in these 
Table 1. Clinical and epidemiological data on oral cancer patients according to smoking habit.

\begin{tabular}{|c|c|c|c|c|c|}
\hline \multirow{2}{*}{\multicolumn{2}{|c|}{ Smoking at diagnosis }} & Smoker & Non-smoker & Total & \multirow{2}{*}{ Significance } \\
\hline & & $56(45.5 \%)$ & $67(54.5 \%)$ & 123 & \\
\hline \multicolumn{2}{|c|}{ Age (mean and SD) } & $\begin{array}{c}53 \text { years and } 7 \\
\text { months }(\mathrm{SD} \pm 9 \\
\text { years) }\end{array}$ & $\begin{array}{c}66 \text { years and } 8 \text { months } \\
\left(\begin{array}{c}\mathrm{SD} \pm 11 \text { years and } 4 \\
\text { months })\end{array}\right.\end{array}$ & $\begin{array}{c}60 \text { years and } 9 \text { months } \\
\text { (SD } \pm 12 \text { years and } 2 \\
\text { months })\end{array}$ & $<0.05$ \\
\hline \multirow{2}{*}{ Gender } & Male & $46(82.1 \%)$ & $30(44.8 \%)$ & \multirow{2}{*}{$45.5 \%$} & \multirow{2}{*}{$<0.05$} \\
\hline & Female & $10(17.9 \%)$ & $37(55.2 \%)$ & & \\
\hline \multirow{7}{*}{$\begin{array}{l}\text { Location } \\
\text { (\&) }\end{array}$} & Gums & $10(17.9 \%)$ & $17(25.4 \%)$ & $22 \%$ & N.S. \\
\hline & Tongue & $25(44.6 \%)$ & $16(53.7 \%)$ & $49.6 \%$ & N.S. \\
\hline & Cheek mucosa & $5 \quad(8.9 \%)$ & $8(11.9 \%)$ & $10.6 \%$ & N.S. \\
\hline & Floor of mouth & $9 \quad(16.1 \%)$ & $\begin{array}{ll}3 & (4.5 \%) \\
\end{array}$ & $9.8 \%$ & $<0.05$ \\
\hline & Palate & $3 \quad(5.4 \%)$ & $2 \quad(3 \%)$ & $4.1 \%$ & N.S. \\
\hline & Lip & 0 & $1 \quad(1.5 \%)$ & $0.8 \%$ & N.S. \\
\hline & $>1$ location & $\begin{array}{ll}3 & (5.4 \%) \\
\end{array}$ & 0 & $2.4 \%$ & N.S. \\
\hline \multicolumn{2}{|c|}{$\begin{array}{l}\text { Time from } 1^{\text {st }} \text { symptom to } 1^{\text {st }} \\
\text { consultation }\end{array}$} & \begin{tabular}{|}
5 months and 5 days \\
$(\mathrm{SD} \pm 7$ months and \\
1 day $)$
\end{tabular} & $\begin{array}{c}4 \text { months and } 4 \text { days } \\
\left(\begin{array}{c}\mathrm{SD} \pm 4 \text { months and } 28 \\
\text { days })\end{array}\right.\end{array}$ & $\begin{array}{c}4 \text { months and } 21 \\
\text { days }(\mathrm{SD} \pm 6 \\
\text { months })\end{array}$ & N.S. \\
\hline \multirow{4}{*}{ Stage $(*)$} & $\mathrm{I}$ & $30(53.6 \%)$ & $44(65.7 \%)$ & $74(60.2 \%)$ & N.S. \\
\hline & II & $10(17.9 \%)$ & $13(19.4 \%)$ & $23(18.7 \%)$ & N.S. \\
\hline & III & $4 \quad(7.1 \%)$ & $3(4.5 \%)$ & $7 \quad(5.7 \%)$ & N.S. \\
\hline & IV & $10(17.9 \%)$ & $4(6 \%)$ & $14(11.4 \%)$ & $<0.05$ \\
\hline \multirow{7}{*}{$\begin{array}{l}\text { Reason for } \\
\text { consultation }\end{array}$} & Casual finding & $11(19.6 \%)$ & $11(16.4 \%)$ & $17.7 \%$ & N.S. \\
\hline & $\begin{array}{c}\text { Nonspecific } \\
\text { discomfort }\end{array}$ & $6(10.7 \%)$ & $4 \quad(6.0)$ & $8.1 \%$ & N.S. \\
\hline & Ulcer & $27(48.2 \%)$ & $27(40.3 \%)$ & $43.9 \%$ & N.S. \\
\hline & Lump (tumor) & $7(12.5 \%)$ & $14(20.9 \%)$ & $17.1 \%$ & N.S. \\
\hline & Pain & $3 \quad(5.4 \%)$ & $\begin{array}{ll}6 & (9.0 \%) \\
\end{array}$ & $7.3 \%$ & N.S. \\
\hline & White spot & $2 \quad(3.6 \%)$ & $\begin{array}{ll}4 \quad(6.0 \%) \\
\end{array}$ & $4.9 \%$ & N.S. \\
\hline & Bleeding & 0 & $1 \quad(1.5 \%)$ & $0.8 \%$ & N.S. \\
\hline
\end{tabular}

Table 2. Changes in smoking habit.

\begin{tabular}{|c|c|c|c|c|c|c|c|c|}
\hline & \multicolumn{7}{|c|}{ Smoking at time of diagnosis of OSCC } \\
\hline & & No & $\begin{array}{c}1-10 \\
\mathrm{cig} / \mathrm{day}\end{array}$ & $\begin{array}{c}11-20 \\
\text { cig/day }\end{array}$ & $\begin{array}{c}21-40 \\
\text { cig/day }\end{array}$ & $\begin{array}{c}41-60 \\
\text { cig/day }\end{array}$ & $\begin{array}{c}>60 \\
\text { cig/day }\end{array}$ & Total \\
\hline \multirow{7}{*}{$\begin{array}{l}\text { Smoking at } \\
\text { time of } \\
\text { interview }\end{array}$} & No & $\begin{array}{c}66 \\
(53.7 \%)\end{array}$ & $8(6.1 \%)$ & $\begin{array}{c}6 \\
(4.9 \%)\end{array}$ & $\begin{array}{c}11 \\
(8.9 \%)\end{array}$ & $7(5.7 \%)$ & 0 & $\begin{array}{c}98 \\
(79.7 \%)\end{array}$ \\
\hline & $1-10 \mathrm{cig} / \mathrm{day}$ & 0 & $1(0.8 \%)$ & $\begin{array}{c}3 \\
(2.4 \%)\end{array}$ & $5(4.1 \%)$ & $2(1.6 \%)$ & 0 & $\begin{array}{c}11 \\
(8.9 \%) \\
\end{array}$ \\
\hline & 11-20 dig/day & 0 & 0 & 0 & $\begin{array}{c}4 \\
(3.3 \%)\end{array}$ & $1(0.8 \%)$ & $1(0.8 \%)$ & $6(4.9 \%)$ \\
\hline & $21-40 \mathrm{cig} / \mathrm{day}$ & $1(0.8 \%)$ & 0 & 0 & $3(2.4 \%)$ & $3(2.4 \%)$ & 0 & $7(5.7 \%)$ \\
\hline & 41-60 cig/day & 0 & 0 & 0 & 0 & $1(0.8 \%)$ & 0 & $1(0.8 \%)$ \\
\hline & $>60 \mathrm{cig} / \mathrm{day}$ & 0 & 0 & 0 & 0 & 0 & 0 & 0 \\
\hline & Total & $\begin{array}{c}67 \\
(54.5 \%)\end{array}$ & $9(7.3 \%)$ & $\begin{array}{c}9 \\
(7.3 \%)\end{array}$ & $\begin{array}{c}23 \\
(18.7 \%)\end{array}$ & $\begin{array}{c}14 \\
(11.4 \%)\end{array}$ & $1(0.8 \%)$ & 123 \\
\hline
\end{tabular}

The values within the heavy broken line correspond to patients who reduced or suppressed smoking.

patients was 27 years and 1 month $(\mathrm{SD} \pm 14$ years and 8 months), with a range of $4-48$ years. The mean time elapsed from smoking cessation to the appearance of OSCC was 13 years and 7 months $(S D \pm 9$ years and 4 months), with a range of 6 months to 30 years.

There were no significant differences in terms of the location of the tumor, with the exception of the floor of the mouth, which was more often affected in smokers than in non-smokers (Table 1).

Most of the patients (78.9\%) were diagnosed in early stages of the disease (I and II), while $17.1 \%$ were diagnosed in advanced stages (III and IV). Tumor stage could not be determined in 5 patients. The number of patients diagnosed in stage IV was significantly greater 
Table 3. Smoking cessation according to smoking at the time of the diagnosis of OSCC.

\begin{tabular}{|c|c|c|c|}
\hline $\begin{array}{c}\text { Smoking at } \\
\text { diagnosis }\end{array}$ & $\begin{array}{c}\text { No. patients } \\
\text { at diagnosis }\end{array}$ & $\begin{array}{c}\text { No. patients at } \\
\text { interview }\end{array}$ & $\begin{array}{c}\% \text { smoking } \\
\text { cessation }\end{array}$ \\
\hline $1-10 \mathrm{cig} /$ day & 9 & 1 & $88.9 \%$ \\
\hline $11-20 \mathrm{cig} /$ day & 9 & 3 & $66.7 \%$ \\
\hline $21-40 \mathrm{cig} /$ day & 23 & 12 & $47.8 \%$ \\
\hline $41-60 \mathrm{cig} /$ day & 14 & 7 & $50 \%$ \\
\hline$>60 \mathrm{cig} /$ day & 1 & 1 & $0 \%$ \\
\hline
\end{tabular}

among smokers than in non-smokers (Table 1).

There were no differences in terms of the initial reason for consultation between smokers and non-smokers. The modifications in smoking habit after cancer diagnosis are reported in (Table 2). A little over one-half of the smokers $(57.1 \% ; \mathrm{n}=32)$ stopped smoking after the diagnosis, while $42.9 \%(n=24)$ continued to smoke. By gender, a full $80 \%$ of the female smokers abandoned the habit, versus only $52.2 \%$ of the males - the difference being statistically significant $(Z s=2.51 ; \mathrm{p}<0.05)$. Among the patients who continued to smoke, only 5 continued to do so to the same extent as at the time of diagnosis, while the rest reduced their smoking habit. One patient began to smoke after the diagnosis of the disease. We found that the greater the smoking habit at the time of the diagnosis, the lower the percentage of smoking cessation (Table 3).

\section{Discussion}

The persistence of modifiable risk factors in patients who have already suffered cancer is associated to high disease relapse risk and to serious limitations in the efficacy of treatment. However, the modification of certain habits is clearly difficult. According to Jazieh et al. (8), less than a quarter of all patients with antecedents of cancer (mean age 68 years) modified their habit in a positive way. Smoking tobacco generates addiction as a result of its nicotine content, which acts upon the central nervous system, causing both physical and psychological dependency. This in turn gives rise to compulsive consumption despite the negative health consequences and the fact that most smokers express a desire to reduce or stop smoking entirely. The effect of nicotine upon the dopamine-related pleasure pathways of the central nervous system, and its special pharmacokinetic characteristics (with a time to effect of just 10 seconds, followed by rapid dissipation), lead smokers to seek continuous dosing throughout the day (9). The literature abounds with strategies designed to abandon the habit, including behavioral therapies (from self-assisting materials to cognitive-behavioral therapy) and drugs. The latter are based on nicotine replacement treatments (patches, chewing gum, sprays, inhalers), antidepressants (bupropion) and varenicline (10). In a systematic review of the interventions designed to facilitate the cessation of non-smoked tobacco use, no significant benefits were observed in terms of pharmacological treatment (bupropion, nicotine patches and nicotine chewing gum). As regards the behavioral interventions, statistical heterogeneity was observed: 6 of the 12 evaluated trials reporting significant benefits, while four reported a nonsignificant tendency towards benefit, and two found no effects (11).

The success of smoking intervention strategies is largely dependent upon the adequate optimization of resources. To this effect, it is very important to adequately identify the corresponding target populations. Patients who have already suffered oral cancer undoubtedly represent a strategic population in this context. The persistence of smoking habit after the diagnosis of head and neck cancer influences both treatment efficacy and patient survival. In patients with head and neck malignancy diagnosed in stages III and IV, survival after two years is poorer among those who continue to smoke than in those who either do not smoke or have abandoned the habit after diagnosis of the disease (39\% versus $66 \%$ ), according to the data published by Browman et al. (12). In that same study, the authors also found the radiotherapy complete response rate to be lower among patients who smoke during the treatment than in those who do not smoke.

There is evidence of the association between persistent smoking habit and an increased frequency of second primary head and neck tumors. Twenty-five years ago, Silverman et al. (13) explored this association in 160 patients with antecedents of the disease who were followed-up on for an average of 4 years and 11 months (range 1-15 years). The authors found the greatest risk of second primary malignancies $(29.7 \%)$ to correspond to patients who failed to modify their smoking habit, while a drastic decrease was noted among those who reduced or abandoned smoking. This suggests the need for a sustained minimum smoking threshold in order to cause cancer. The sample in the study published by Silverman et al. (13) was similar to our own in terms of mean age (58 versus 60 years in our series), gender distribution ( $44 \%$ females versus $38 \%$ ) and preferential tumor location in the tongue ( $43.8 \%$ versus $44.6 \%)$. How- 
ever, there were differences in the amount of tobacco consumed $(86 \%$ heavy smokers, i.e., over one packet of cigarettes/day, versus $66.7 \%$ ) and in the percentage of smokers at diagnosis (73\% versus $45.5 \%)$. In contrast to our study, the mentioned authors included nasopharyngeal, oropharyngeal and laryngeal cancers in their series. In their group of 117 smokers followed-up on during $1-15$ years, $32 \%$ of the patients did not modify their smoking habit, $23 \%$ reduced smoking, and $45 \%$ stopped smoking. Percentage smoking cessation was comparatively higher in our study (57.1\%). Likewise, 33.9\% of our patients reduced their smoking habit, while $8.9 \%$ continued to smoke as much as before. The lesser percentage smoking cessation reported by Silverman et al. (13) may possibly be related to the greater percentage of heavy smokers in their series. In accordance with our own observations, heavy smokers (over one packet of cigarettes a day) show lower cessation rates than those patients who smoke less than one packet of cigarettes a day $(44.7 \%$ versus $77.8 \%)$.

Do et al. (14), in a randomized chemical prevention study involving 13-cis-retinoic acid in early-stage head and neck cancer, conducted a longitudinal sub-study to assess the correlation between smoking-related second primary tumors and cigarette smoking habit in 1190 patients diagnosed with stage I and II squamous cell carcinoma of the upper airway and digestive tract. They found that $12.7 \%$ of the patients had never smoked - in strong contrast to the $35 \%$ in our own series. A total of $55.1 \%$ of their patients remained non-smokers at the time of the evaluation; this was slightly higher than the $45.4 \%$ recorded in our study. In turn, the above authors found $12.3 \%$ of their patients to start smoking after the diagnosis, versus only $0.8 \%$ in our series (a single patient). Their recorded hazard ratio for second primary tumors was 2.75 (confidence interval 1.49-5.07) among the patients who continued to smoke versus those who had never smoked. The mean duration of follow-up was similar in both studies (4 years and 6 months versus 4 years and 10 months).

Some authors have reported data in contrast to the above. Tomek and McGuirt (15) found no differences in a group of 91 patients with second primary head and neck tumors between those who continued to smoke after the diagnosis and those who stopped smoking. In that study, 88 of the 91 patients with second primary head and neck tumors were smokers at the time of the diagnosis of the first tumor - thus evidencing a clear association between smoking and the appearance of second primary tumors. These data are very similar to those published by Schwartz et al. (16).

In our study no protocolized strategy was used to promote smoking cessation among the patients other than the provision of information on the importance of cessation in relation to the prognosis of the disease. In a controlled trial carried out by Gritz et al. (17), comparisons were made of the efficacy of a structured intervention program that included physician counseling to stop smoking, written material and reinforcement sessions, versus an intervention similar to our own. The authors found no significant differences in smoking habit between the two groups one year after the intervention. One of the reasons given by the authors to explain the lack of efficacy was the high smoking cessation rate in the control group (76.8\%). However, some publications (18) have reported similar cessation rates without any type of protocolized intervention (67.3\%). In our study, percentage smoking cessation was $51.7 \%$, though it must be underscored that the average follow-up was 4 years and 6 months versus only one year in the two studies commented above.

Compared with other health professionals, dental surgeons have a more precise notion of the smoking habits of their patients. However, over $40 \%$ of all dental surgeons fail to systematically ask their patients about smoking, and $60 \%$ do not systematically recommend smoking cessation (19).

In conclusion, $44.4 \%$ of all patients diagnosed with OSCC continue to smoke despite warnings about the risks involved, and although the majority claim to have reduced smoking, intervention measures are needed to help ensure complete and permanent smoking cessation in view of the risk of tumor relapse and the appearance of new lesions even with low levels of tobacco use.

\section{References}

1 1. Stewart SL, Cardinez CJ, Richardson LC, Norman L, Kaufmann $\mathrm{R}$, Pechacek TF, et al. Surveillance for cancers associated with tobacco use--United States, 1999-2004. MMWR Surveill Summ. 2008;57:1-33.

2. Bagan JV, Jiménez Y, Murillo J, Poveda R, Díaz JM, Gavaldá C, et al. Epstein-Barr virus in oral proliferative verrucous leukoplakia and squamous cell carcinoma: A preliminary study. Med Oral Patol Oral Cir Bucal. 2008;13:E110-3.

3. Bagan JV, Scully C. Recent advances in Oral Oncology 2008; squamous cell carcinoma aetiopathogenesis and experimental studies. Oral Oncol. 2009;45:e45-8.

4. Nozad-Mojaver Y, Mirzaee M, Jafarzadeh A. Synergistic effects of cigarette smoke and saliva. Med Oral Patol Oral Cir Bucal. 2009;14:E217-21.

5. Vineis P, Alavanja M, Buffler P, Fontham E, Franceschi S, Gao YT, et al. Tobacco and cancer: recent epidemiological evidence. J Natl Cancer Inst. 2004;96:99-106.

6. Petti S. Lifestyle risk factors for oral cancer. Oral Oncol. 2009;45:340-50.

7. Polesel J, Talamini R, La Vecchia C, Levi F, Barzan L, Serraino $\mathrm{D}$, et al. Tobacco smoking and the risk of upper aero-digestive tract cancers: A reanalysis of case-control studies using spline models. Int J Cancer. 2008;122:2398-402.

8. Jazieh AR, Foraida M, Ghouse M, Khalil MM, Kopp M, Savidge $\mathrm{M}$. The impact of cancer diagnosis on the lifestyle and habits of patients served at a Veterans Administration Hospital. J Cancer Educ. 2006;21:147-50.

9. Benowitz NL. Pharmacology of nicotine: addiction and therapeutics. Annu Rev Pharmacol Toxicol. 1996;36:597-613.

10. The Agency for Health Care Policy and Research Smoking Ces- 
sation Clinical Practice Guideline. JAMA. 1996;275:1270-80.

11. Ebbert JO, Montori V, Vickers KS, Erwin PC, Dale LC, Stead LF. Interventions for smokeless tobacco use cessation. Cochrane Database Syst Rev. 2007;4:CD004306.

12. Browman GP, Wong G, Hodson I, Sathya J, Russell R, McAlpine $\mathrm{L}$, et al. Influence of cigarette smoking on the efficacy of radiation therapy in head and neck cancer. N Engl J Med. 1993;328:159-63.

13. Silverman S Jr, Gorsky M, Greenspan D. Tobacco usage in patients with head and neck carcinomas: a follow-up study on habit changes and second primary oral/oropharyngeal cancers. J Am Dent Assoc. 1983;106:33-5.

14. Do KA, Johnson MM, Lee JJ, Wu XF, Dong Q, Hong WK, et al. Longitudinal study of smoking patterns in relation to the development of smoking-related secondary primary tumors in patients with upper aerodigestive tract malignancies. Cancer. 2004;101:2837-42.

15. Tomek MS, McGuirt WF. Second head and neck cancers and tobacco usage. Am J Otolaryngol. 2003;24:24-7.

16. Schwartz LH, Ozsahin M, Zhang GN, Touboul E, De Vataire F, Andolenko P, et al. Synchronous and metachronous head and neck carcinomas. Cancer. 1994;74:1933-8.

17. Gritz ER, Carr CR, Rapkin D, Abemayor E, Chang LJ, Wong WK, et al. Predictors of long-term smoking cessation in head and neck cancer patients. Cancer Epidemiol Biomarkers Prev. 1993;2:261-70. 18. Spitz MR, Fueger JJ, Chamberlain RM, Goepfert H, Newell GR. Cigarette smoking patterns in patients after treatment of upper aerodigestive tract cancers. J Cancer Educ. 1990;5:109-13.

19. Tomar SL. Dentistry's role in tobacco control. J Am Dent Assoc. 2001;132 Suppl:30S-35S. 